\title{
Factors Affecting Hotel investment in Ethiopia: Evidence from South Gondar Administrative Zone, Ethiopia
}

\author{
Amare Kindu Abebe \\ Department of Tourism and Hotel Management Debr Tabor University \\ Tadesse Bekele \\ Department of Tourism and Hotel Management Bahir Dar University \\ Amare Yaekob \\ School of Hotel and Tourism management, Hawassa University
}

\begin{abstract}
The main objective of this study was to examine the factors affecting hotel investment in the case of South Gondar Administration Zone. Descriptive and Explanatory research design and mixed research approach were applied. The data was collected through structured questionnaire and semi- structured interviews. 220 sample respondents were selected for survey questionnaire and 9 informants were selected for interviews. The key informants were selected via purposive and multi-stage stratified sampling. The study was employed both descriptive statistics inferential statistics using SPSS Version 26. On the other hand, the five independent variables namely government policy, infrastructure, socio-cultural, location, and economic factors affect hotel investment. Based on the findings of the study, the researcher recommended that investment and land administration office could be make standard and feasible policy for hotel investor to minimize the complexity of policy.
\end{abstract}

Keywords: Investment, Hotel, South Gondar Zone, Ethiopia, factors,

DOI: $10.7176 / \mathrm{JTHS} / 58-01$

Publication date:August $31^{\text {st }} 2021$

\section{Introduction}

The hotel industry is a business establishment which deals with accommodation, meals, entertainment, and health club for any potential guests within the particular location without time limitation. Hotels are multistory facilities with a widespread food, banquet services, and beverages, pleasant car parking lot, enough interior and exterior designs, and clean public areas (Rushmore et al., 2001; Oxford dictionaries, 2014). It is characterized by labor- intensive and source of employment opportunity (Goldin, 2010). Even though, investment has the above distinctive significance, the meaning and understanding are vague due to different discipline relativity.

For instance, Mankiew (2012) investment is the amount of spending today for the further economical purpose and it is the component of national income that links with the further ultimate goal of economic and social benefits. Hotel investment is may be owned and/or managed by independent operators, multinational chains, insurance companies, pension funds, governments, and other investors (International Labor Organization [ILO], 2010). Yet, of these many different investment sectors, is under the most challenging condition. as Melegarejo (2012) the hotel industry is an investment that brings a multibillion-dollar per year and serving millions of people globally, and this investment could be expected to grow significantly within the next few years. Meanwhile Paker, (2010) hotel investment is the movements of business transaction which improve the degrees of real aggregate wealth in the national economy. It includes the process of purchasing, production of new durable assets like machines and factories

Moreover, according to Matwanga (2010) investment can solve huge economic and social problems such as alleviating poverty, adopting new technology, creating employment opportunities, contributing to growth economic level, and improve living standards at the national and local base. In Ethiopia, the modern history of what is now known as the "Ethiopian hospitality industry" dates back to more than 100 years with the opening of the first hotel called Taitu Hotel. Taitu Hotel was established in 1895 by Empress Taitu Bitul (Kebede, 2014). South Gondar Zone is among the Zones located in Amhara Region, Ethiopia which holds attractive tourism resources. Regardless of the big potentials of the zone for tourism development, hotel investment in the study area does not seem to cope with potential customers/guests.

\subsection{Statement of the Problem}

Despite the long history of its existence, a few studies were conducted in the hotel investment in the world. For instance, Ebisa et al (2013) conducted a study on hotel sector investment in Ethiopia. Geographically, the researcher focused on the demand and supplies of hotels in Addis Ababa and generalized that there is no escalating demand for an international standard hotel in Addis Ababa. But in this research, the authors could not 
address basically the factors that might affect the hotel investment in the city. In addition to this, regarding the methodology of the study, the authors used only secondary data sources from journals, books, newspapers, magazines, and reports of various governmental and non-governmental organizations only. Moreover, Josephine and Ronnie (2010) conducted a study on investment challenges in the hotel industry in Kigali, Rwanda: methodologically, the researcher was focused on descriptive types of research and the data were collocated from hotel manager's perception and opinions. As a result they were revealed that lack of skilled labor, lack of finance in the form of loans to potential investors, and the lack of adequate infrastructure is the major challenge of hotel investment in the study area. But the researcher did not considered the basic variables that affect the hotel investment namely location, government policy, and socio-cultural factors as the challenge of hotel investment. According to Tesfaye (2018) output/national income, public investment, and exchange rate were the critical variables affecting the performance of tourism and hotel, trade, agriculture, and health investment in Nekemte town. Here it possible to understand that the author investigated variables that affect four economic sectors which are very difficult to identify which variable affects only the hotel investment in the city. Similarly, Girmachew and Gashaw (2018) conducted a paper entitled challenges and opportunities for investment in Ethiopia. Agriculture, industry, construction, tourism, hotel, social sector, \& mining were target sectors for the study; this implies that it is also hard to identify which factors affect the hotel sector investment in the study area. Krisada (2019) conducted research on the factors affecting decisions on investment patterns for financial problem-solving in the accommodation business. The author revealed that variables like infrastructure, geography, and market demand were the major factors that affect investors' decision making. Similarly, Graeme and Ross (2006) found that economic, financial, and location factors were influencing hotel investment decision making. But the researchers did not consider other variables like socio-cultural factors, economic, and government policy as a study variable. Therefore, this study is intended to fill the knowledge gap in relation to factors affecting hotel investment in South Gondar Administrative Zone, Ethiopia. Its objectives are three fold: (1) to assess the current situation of hotel investment practice in South Gondar Zone; (2) to determine the major factors that affect hotel investment in the south Gondar zone; and (3) to examine the strength of each major factor on hotel investment in the south Gondar zone. This research paper also holds three basic research question (1)what does the existing situation of hotel investment look like in the South Gondar Zone?; (2)what are the major factors that affect hotel investment in south Gondar Zone? And (3) which factors severely affect hotel investment in south Gondar zone?

\section{LITERATURE REVIEW}

Even though the decision making of hotel investment in every company is not be the same due to differences in cultural and organizational behavior, it can be observed that there are similarities in the process that consist of at least six phases as given in quoted at least five (Recognition phase, Searching phase, Information retrieval phase, Selection phase, Funding phase) more typical studies which have similar findings (Niskanen 2007; Tiainen, 2009; Niskanen, 2013).

Hotel investment can is passed through various analysis types such as; economic analysis, strategic analysis, location attractiveness analysis, and risk analysis (Russell, 2007). economic analysis of the primary analysis that contains cash flow, net present value( NPV), internal rate of return (IRR) profitability of index (PI) return on investment(ROI), and payback time. The other investment analysis is strategic analysis. Strategic analysis is the holistic view and understanding of the hotel industry (Mariana et al, 2016). Risk analysis is also another of the hotel investment analysis approaches. It used to determine of potential risk which might happen at the hotel investment at the time of the investment period. It contain at least six steps such as the decision of making risk analyses, risk recognition and evaluation, reporting of possible risk, risk consequence measurement evaluation, the recommendation of actions and implementation, and monitoring (Niskanen, 2007; Taqadus \& Bashir, 2013). The other type of investment analysis is environmental attractiveness. In order to maintain the hotel investor needs to recognize the attractiveness of location like labor, tax climate, amenity, higher education, School, regulation, energy, communication, and business movement (Kotler\& Gertner, 2010). Hotel investment can be affected by (1)Government Policy- Factors like rule and regulation, future government legislation, government policy, government term and change, international conflict group, home market, funds mechanism, incentives style, and term, grant and initiatives, regulatory bodies and process of license and also government bureaucracy Nosta (2012). (2) Socio-cultural factors such as improvement of recreational activity sprits like the feeling of local community and identity, good or bad relationship between the local community and guests, and quality of life among the local community as the associate community traditional values, norms, and identities, and awareness with socio-cultural factors Zamani and Musa (2012) and (Xiaoping et al, 2019). (3)Location factors like: distance from the airport access, capacity of tourism demand on the geographical location and increasing amount of distance from the capital city (Tzeng et al, 2002; Newell, 2006; Puciato, 2016; Januszewska \& Januszewski, 2009; Wojciech et al, 2018). (4) Infrastructure Factors such as changes in tourism infrastructure like an airport, convention center, new communication infrastructure like digital terrestrial television (DTT), the 
wider geographical coverage of broadband internet, enough water supplies, good accessible health service, and facilities in the investment area, electric power supply, banking, road and insurance service (Callen \& Hoyes, 2000Juan et al 2011). (5) Economic Factors namely economic system of the country, government intervention in the free market, exchange rate and suitability of host country currency, the efficiency of the financial market(the local investment market), the quality of tourism infrastructure, total economic advantages of the host country, skilled level of workforce and their costs, the level of education in the country economy, the local economic business cycle stage, economic growth rate, average incomes of the local community, unemployment rate, inflation and interest rate are the major factors that affect the hotel investors in various ways (Sudhan et al 2012 Nosta2012).

\section{METHODOLOGY OF THE STUDY}

To achieve the intended research objectives and to reach a more factual report researchers applied descriptive and explanatory research methods using mixed research approaches. The target population for this study was governmental and non-governmental bodies. For this study, the sample frame consisted of 490 total target populations with different stakeholders of hotel investment in the zone such as Hotel owners, Hotel managers, and Investment office officers, and culture and tourism office. The data were collected from Debre Tabor town, Lay Gaynet, Woreta, Addis zemen, Mekan Eyesus, and Andabet towns.

The researchers have applied both probability and non-probability sampling techniques. From probability sampling multi-stage stratified random sampling with proportional allocation was used to choose respondents from hotel investors, culture and tourism offices, hotel managers, and investment office. In the first stage, the researcher selected the group of the target population from each district. Then, different groups of population (strata) were identified and sampling frames were determined. Finally, a systematic sampling technique was applied to select the target respondents. The procedure started in determining the first respondents to be included in the sample. Then, the technique is taken the kth item from the sampling frame and then chose a number between one and $\mathrm{K}$ in the random table (Cochran, 1997).

From non-probability sampling technique purposive sampling was used to select hotel managers, investment office officers, hotel and tourism experts, municipality offices, land administration office officers, revenue office officers, and culture and tourism office officers for interview purposes. The sample size was cualculated by using the formula which was developed by Yeman (1967), because sample was taken from finite population.

$n=\frac{N}{1+N\left(e^{2}\right)}$

Where: $\mathbf{n}=$ corrected sample size, $\mathrm{N}=$ total target population $(490), \mathbf{e}=$ margin of error (0.05)

$$
n=\frac{490}{1+490\left(0.05^{2}\right)}=220
$$

This research was compiled both primary and secondary sources of data via questionnaire and interview as the basic data collection instruments. As much as possible, content analysis was applied for additional data collection.

The quantitative data was analysed and interpreted using quantitative techniques which includes descriptive statistics such as; mean and standard deviation and inferential statistics method such as: Pearson correlation coefficient, to test how strong relationship exists between dependent and independent variables and regression analysis was used to measure the effect of independent variables on the dependent variable. Then, the study has applied multiple linear regression analysis, because the study involves more than two independent variables. Statistical package for social science (SPSS) version 26 software packages was used as a tool for primary data computations. Indeed, in this research the qualitative data are analysed through thematic analysis and also researcher used the direct quotation of respondents including the organization / where they came.

\section{Description of Variables}

Multiple regression analysis formula were

$\hat{Y}=\hat{\beta}_{0}+\hat{\beta}_{1} X_{1}+\hat{\beta}_{2} X_{2}+\hat{\beta}_{3} X_{3}+\hat{\beta}_{4} X_{4}+\hat{\beta}_{6} X_{5}$

Where $\mathrm{Y}$ is dependent variable that is hotel investment

$\hat{\beta}_{o}=$ represent the intercept term. The intercept is defined as the average value of dependent variable $(\mathrm{Y})$ when the effect of independent variables $(\mathrm{X})$ is eliminated.

$\hat{\beta}_{1}, \hat{\beta}_{2}, \ldots, \hat{\beta}_{5}$ are representing the Regression coefficient. The partial regressions coefficient represents the change in the dependent variable is changed by one unit and other dependent variables are held constants.

$X_{1}, X_{2}, \ldots, X_{5}$ are independent variable

$X_{1}=$ government policy

$X_{2}=$ socio-cultural 
$X_{3}=$ economy

$X_{4}=$ location

$X_{5}=$ infrastructure

Reliability of internal consistency was measured by using Cronbach Alpha coefficient for multiple-item scales. Hence, independent variables namely Government policy.864, Economy.804, Location.806, Socio-cultural.803, Infrastructure.808, and dependent variable which is Hotel investment has .806

\section{Result and discussion}

\section{The existing Situation of hotel investment in South Gondar Zone}

* Hotel distribution and numbers

South Gondar Administrative Zone is the home of both natural and cultural tourist attractions and it is ideal and suitable for different types of tourism activities. Even if the Zone is resource full for tourism sector, it has few hotels in number which deliver services for customers. Hotels which are located in the main towns of the zone engaged with limited services and products mainly focused on preparing and delivering food and beverage (south Gondar zone culture and tourism office [SGAZCTO], 2020).

\begin{tabular}{|c|c|c|c|}
\hline N.o & Location & No. of hotels & No. of rooms \\
\hline 1 & Debre Tabor & 21 & 255 \\
\hline 2 & Addis Zemen & 19 & 173 \\
\hline 3 & Andabet & 7 & 56 \\
\hline 4 & Woreta & 30 & 326 \\
\hline 5 & L/Gayint & 15 & 120 \\
\hline 6 & M/Eyesus & 10 & 103 \\
\hline Total & - & 116 & 1,033 \\
\hline
\end{tabular}

As the Table 7 indicates, the total number of hotels in the Zone is 116 out of this Woreta (30) has the highest number of the hotel followed by Debre Tabor Town (21). Other towns also have few hotels engaged in delivering basically food and beverage services for tourists and other travelers.

An Interviewee from South Gondar Zone Culture and Tourism Office stated the number of hotels as follows:

... Currently, the South Gondar Administration Zone has a total number of 116 hotels with a total numbers of 1,033 rooms which are very important particularly for the development of the zone and for the country as well. Based on the flow of customers into the South Gondar Zone, the number of hotels serving customers is not enough and has the problem to provide a variety of products that they deliver and the quality of service rendered. But what I want to say is the current number of hotels is not enough for the future because we expect a good flow of tourists with high-quality service demand.

\section{* Hotels under plan in South Gondar}

The number of hotels in the South Gondar Zone is smaller and in this regard, the South Gondar Zone has less competitiveness to attract big conferences. According to the South Gondar Zone Investment Office and land administration office head, 10 Hotels are planned to be constructed but it is not clear how long it will take to complete such plans.

..Accordingly, those investors started a new hotel building South Gondar Administration Zone.

From those hotels, two hotels are run by five partners and the rest eight hotels are being built by individual owners. Even though those hotels are under the construction level the unbalanced demand and supply of input such as cement, building cleat and inflations are a serious obstacle for hotel investors to be completed in short period of time.

\section{* Employments}

Hotels in the South Gondar Zone are not currently run and managed by sector professionals and those who did not know the sector. Currently, there are 937 employees in total in the zone working in the hotel sector, but the majority of employees did not have a hotel related educational background. Only 228 employees have a hotelrelated professional background (SAGZCTO, 2020).

Hotels in the South Gondar Zone are currently is not run and managed by sector professionals. Currently, there are 937 employees in total in the zone working in the hotel sector, but the majority of employees do not have a hotel related educational background. Only 228 employees have a hotel-related professional background (SAGZCTO, 2020).

An informant interviewee from the culture and tourism office, experts and hotel managers said that: "There is a big problem of managing and running the sector with the right professionals that make the sector to be weak in providing excellent service." 
Table 1:List of employee's background

\begin{tabular}{|c|c|c|c|c|c|c|c|}
\hline \multirow{2}{*}{ N.o } & \multirow{2}{*}{ Location } & \multicolumn{6}{|c|}{ Employees background } \\
\cline { 3 - 7 } & & \multicolumn{2}{|c|}{ Professional and experienced } & \multicolumn{3}{c|}{ Non professional } \\
\cline { 3 - 8 } & & $\mathrm{M}$ & $\mathrm{F}$ & $\mathrm{T}$ & $\mathrm{M}$ & $\mathrm{F}$ & $\mathrm{T}$ \\
\hline 1 & Debre Tabor & 29 & 27 & 56 & 70 & 144 & 214 \\
\hline 2 & Addis Zemen & 20 & 23 & 43 & 8 & 44 & 52 \\
\hline 3 & Andabet & 3 & 4 & 4 & 6 & 17 & 23 \\
\hline 4 & Woreta & 25 & 20 & 45 & 56 & 139 & 195 \\
\hline 5 & L/Gayint & 12 & 11 & 27 & 25 & 44 & 69 \\
\hline 6 & M/Eyesus & 13 & 10 & 23 & 21 & 50 & 71 \\
\hline & Total & 117 & 111 & 228 & 205 & 474 & 709 \\
\hline
\end{tabular}

Source: SGAZCTO (2020)

A Key informant has explained the hotel management practice in the area as follows:

... currently, from the total numbers of hotel investors in the South Gondar Zone the majority of hotel investors are male and the only 9 investors are female. The whole hotel investors are domestic. Regarding managing a hotel, from the total hotels found in the South Gondar Administrative Zone, there are only 12 hotels which are managed by hotel and tourism management professionals; on the other hand, the rest 104 hotels are managed by owners themselves who have no hotel or tourism-related professional background.

The other key informant also describes as:

Hotel owners are still employing non-professional employees and family members rather than hiring qualified employees. Employees have international language barriers to communicate with international guests and hotels on the other hand still they are not applying international reservation software applications. As a result, this leads to a negative image of hotel guests, which later reduces the number of guests using hotel services and products.

The above explanations are directly related to the previous research which was conducted by Milota et al (2019). The authors stated that levels of education determine the quality of their performance at work and their personal stability thus can influence hotel business stability. In addition to this, they also revealed that increasing hotel employee turnover in the hotel industry hurts the quality of service provided as well as customer satisfaction. Then the hotel manager/ owner are forced to replace new employees to secure smooth hotel operations. The newly hired hotel employees need to be trained and instructed which has negative effects on hotel revenue.

\section{* Skill gap training}

Skill gap training is the activity of learning from which employees acquire and enhanced the knowledge, ability, and skills needed by the employees that lead to changes in behavior and attitude to meet the desired goal of the organization. Therefore, training is performance driven and used in work environments (Monappa \& Saiyadain, 2008; Mathis \& Jackson, 2008; Go, 1990 as cited from Dysvik \&Kuvaas, 2008; Armstrong, 2009).The key informant say that "South Gondar zone culture and tourism offices, hotel investors, and experts are working with the collaboration of Debre Tabor University, Woreta, Addis Zemen, Lay-Gayint, and Debre Tabor Polly Technic Colleges to empower the hotel employees."

\section{* Services of Hotels in South Gondar Zone}

In modern times, hotel service is measured based on the hotel facility, size of the hotel, location of the hotel, weather aspects of the hotel business, and business policy. Based on these criteria, hotel service can be classified into; accommodation service (rooms), food and beverage service, banqueting room, banquet hall, lounges, breakfast room, grillrooms, coffee shop, cocktail bar, and room service. In addition to the above, criteria for hotel classification include-service of recreation and sports access, tennis court and golf course, gyms, bowling alley, walking, and jogging paths, and various events that can be organized (Ivica, 2016).

Hotels in the South Gondar Zone are delivering different services for different customers coming for different purposes.

The key informants stated the following core point regarding current practices of hotel service:

...most hotels are delivering common and limited services. Hotels in the zone have problems

delivering variety, standard, and customized service. They do not deliver other basic facilities

like the swimming pool; and most hotels don't provide internet services for customers and health clubs...

Furthermore, today hotels are providing different services including room service, food, and beverage service, conference hall rent service, wedding stage service. But hotels are not capable of delivering additional services like Gymnasium service, compatibles WI-FI service, lift service, shuttle service and they have no handicapped room and handicapped floor for disabled guests.

"South Gondar Zone has no investment web-sites. So, it is difficult to get information about 
investment issues based on online media. Hence, hotel investors access investment information from the South Gondar Zone through personal contact, representatives, and telephone call."

* Marketing and promotion techniques

Promotion, in its gist form, can be defined as a tool of the marketing mix, consists of communicational efforts to persuade the consumers to accept the services offered in the tourist market (Kozak, 2006).

An interview with key informants of South Gondar Zone Culture and Tourism Office stated that,

Hotel investors do not promote their services and products via electronic media because of fearing high promotion payment. Unless they promote their hotel products and services through personal contact, word of mouth promotion and use the mechanisms of keeping the loyal guests, printing media (brochure and flyer) they would not get enough profit and return.

In this regard, the key informant describes that to attract hotel investors;

.... currently the local government is trying to promote the zone in terms of formulating free land use policy, promoting the pattern of the zone via mass media, keeping, restoration and conservation of heritage sites especially great industrial village, creating zonal based geographical positioning system (GPS) with the collaboration of Deber tabor university to identify the zone's heritage site easily for tourists and hotel investors and the zone is also trying to create investment website.

"....hotel investors are not willing to promote their hotel via electronic media due to high cost and they have low motivation to innovation and modify the services and low interest to develop their hotel into category star rated hotel.",

\section{Mean Ratings of Study Variables}

The findings revealed that Socio-cultural (mean value $=4.1339 \mathrm{SD} .61666$ ) has a mean value above the group mean (3.6), on the other hand, Government policy (mean value $=3.5024$, SD.66096), Infrastructure (mean value $=3.5589$, SD. 84900), location (mean value $=3.558$, SD.84900) and Economy (3.2808, SD, .85007) has below the average mean. But they are above the standard mean value except for the economic factor. Hence the above predictors have the importance of retaining hotel investment concerning the study area. Generally, all independent variables that are socio-cultural, government policy, infrastructure, location, and economic factors are very important predictors for hotel investment at various levels.

4.5.1 Correlation

\begin{tabular}{|l|l|l|r|r|r|r|r|}
\hline \multicolumn{2}{|c|}{} & $\begin{array}{l}\text { Hotel } \\
\text { investment }\end{array}$ & Policy & $\begin{array}{c}\text { Socio- } \\
\text { cultural }\end{array}$ & location & Infrastructure & Economy \\
\hline \multirow{2}{*}{$\begin{array}{l}\text { Hotel } \\
\text { investment }\end{array}$} & Pearson Correlation & 1 & $.843 * *$ & $.796 * *$ & $.347 * *$ & $.574 * *$ & $.302 * *$ \\
\cline { 2 - 9 } & Sig. (2-tailed) & & .000 & .000 & .000 & .000 & .000 \\
\cline { 2 - 9 } & $\mathrm{N}$ & 209 & 209 & 209 & 209 & 209 & 209 \\
\hline
\end{tabular}

**. Correlation is significant at the 0.01 level (2-tailed).

Source: own survey (2020)

Accordingly, an attempt was made to examine the relationship between hotel investment and independent variables that are government policy, socio-cultural, location, infrastructure, and economy by computing KarlPearson correlation coefficients. Hence, the independent variables like government policy, socio-cultural, location, infrastructure, and economy were found to be significantly associated with hotel investment with varying degrees.

\section{Regression Assumptions}

$\checkmark$ Normality Assumption

\begin{tabular}{|l|c|c|c|c|c|}
\hline \multicolumn{1}{|c|}{ Descriptive Statistics } \\
\cline { 2 - 6 } & Statistic & Statistic & Std. Error & Statistic & Std. Error \\
\hline Hotel investment & 209 & -0.256 & 0.168 & -0.876 & 0.335 \\
\hline Socio-cultural & 209 & -0.388 & 0.168 & -0.370 & 0.335 \\
\hline Location & 209 & -0.740 & 0.168 & 0.022 & 0.335 \\
\hline Infrastructure & 209 & -1.365 & 0.168 & 1.808 & 0.335 \\
\hline Economy & 209 & -1.331 & 0.168 & 1.611 & 0.335 \\
\hline Government policy & 209 & -558 & 0.168 & 0.109 & 0.335 \\
\hline
\end{tabular}

Source: own survey (2020) 
Multi Co-Linearity Test

\begin{tabular}{|l|l|c|c|}
\hline \multirow{3}{*}{ Model } & \multicolumn{3}{|c|}{ Coefficients } \\
\cline { 2 - 4 } & \multicolumn{1}{|c|}{ Multi co-linearity Statistics } \\
\hline \multirow{4}{*}{1} & Socio-cultural & Tolerance & \multicolumn{1}{c|}{ VIF } \\
\cline { 2 - 4 } & Location & 0.262 & 3.810 \\
\cline { 2 - 4 } & Infrastructure & 0.669 & 1.495 \\
\cline { 2 - 4 } & Economy & 0.562 & 2.779 \\
\cline { 2 - 4 } & Government policy & 0.474 & 4.750 \\
\hline
\end{tabular}

a. Dependent Variable: Hotel investment

Source: own survey (2020)

According to Douglas et al, (2012) stated that the multi-co-linearity Statistics of tolerance and variance inflation factors should be greater than 0.1 (tolerance) and less than 10 (VIF) values for each variable. As the result, the tolerance values for the variables are greater than 0.1 and all VIF values are less than 10 . Hence, it proves that none of the explanatory variables have any multi-co-linearity effect.

\section{$\checkmark$ Auto- correlation}

Autocorrelation was conducted to assess whether residual values are independent or not. The assumption was tested by using Durbin- Watson test. Durbin- Watson value closer to 2 implies that the residuals are independent (Brook, 2008). As can be seen from the model the Durbin- Watson value is 1.621 which falls in the acceptable range.

Multiple linear regression

\begin{tabular}{|l|c|c|c|c|c|}
\hline \multicolumn{7}{|c|}{ Model Summary } \\
\hline Model & $\mathrm{R}$ & R Square & Adjusted R Square & Std. Error of the Estimate & Durbin-Watson \\
\hline 1 & $.892^{\mathrm{a}}$ & .796 & .791 & .43504 & 1.621 \\
\hline
\end{tabular}

a. Predictors: (Constant), Location, socio-cultural, government policy, infrastructure, economy

b. Dependent Variable: Hotel investment

Source: own survey (2020)

As can be seen in Table above the model summary shows that the predicted variances of the variables. It can be observed that $\mathrm{R}$ represents multiple correlation coefficients which have a value of 0.892 stating a high correlation among the predictors and the dependent variable. R-value $(0.892)$ for independent variables namely location, socio-cultural, government policy, infrastructure, economy suggested that there is a strong effect of those five independent variables on hotel investment. On the other hand, R Square shows a value of 0.796 which predicts the variables with $79.6 \%$ variance is due to the included independent variables. It implies that the independent variables have a high factor on the dependent variables (hotel investment). Adjusted R square measures the proportion of variance in the dependent variable explained by the independent variables. That is 79.1 percent of the variation of hotel investment can be explained by the predictors after adjusting other predictors.

\subsubsection{ANOVA Test}

\begin{tabular}{|l|l|c|c|c|c|c|}
\hline \multicolumn{9}{|c|}{ ANOVA $^{\mathbf{a}}$} & S & Sig. \\
\hline \multirow{3}{*}{ Model } & Sum of Squares & Df & Mean Square & F & $.000^{\mathrm{b}}$ \\
\hline \multirow{3}{*}{1} & Regression & 149.818 & 5 & 29.964 & 158.318 & \\
\cline { 2 - 8 } & Residual & 38.420 & 203 & .189 & & \\
\cline { 2 - 8 } & Total & 188.239 & 208 & & & \\
\hline
\end{tabular}

a. Dependent Variable: Hotel investment

b. Predictors: (Constant), Location, socio-cultural, government policy, infrastructure, economy

Source: own survey (2020)

The above shows that demonstrates the analysis of variance (ANOVA) of regression analysis between independent variables and dependent variable. In a regression model, the ANOVA F statistic tests whether the model as a whole is significant. And, it is used to identify whether the independent variables predict the dependent variable better than just predicting the mean for everything. F-ratio, which is the value of 158.318, is significant. The p-value (in the Sig. column) is very low, less than .001. So there is less than a 1 in 100 chance that the relationship we found in this sample is actually best described by a flat line. As a result, the ANOVA table shows that the combination of the variables significantly predicts the dependent variable and the model was fit that enables the researcher to proceed to further analysis. 
Summarized Beta Coefficients of the Regression Model Coefficients

\begin{tabular}{|c|c|c|c|c|c|c|}
\hline \multicolumn{7}{|c|}{ Coefficients } \\
\hline \multirow{2}{*}{\multicolumn{2}{|c|}{ Model }} & \multicolumn{2}{|c|}{ Unstandardized Coefficients } & \multirow{2}{*}{$\begin{array}{c}\begin{array}{c}\text { Standardized } \\
\text { Coefficients }\end{array} \\
\text { Beta }\end{array}$} & \multirow[t]{2}{*}{$\mathrm{T}$} & \multirow[t]{2}{*}{ Sig. } \\
\hline & & $\mathrm{B}$ & Std. Error & & & \\
\hline \multirow{6}{*}{1} & (Constant) & -.180 & .231 & & -.776 & .439 \\
\hline & Government policy & 1.040 & .099 & .722 & 10.451 & .000 \\
\hline & Socio-cultural factor & .337 & .069 & 0.301 & 3.550 & .000 \\
\hline & Economy factor & .240 & .065 & .215 & 3.471 & .001 \\
\hline & Infrastructure factor & .155 & .043 & .138 & 3.567 & .000 \\
\hline & Location factor & .153 & .095 & .100 & 2.369 & .019 \\
\hline
\end{tabular}

a. Dependent Variable: Hotel investment

Source: own survey (2020)

The above table shows that the regression analysis identifies the most contributing, independent variable in the prediction of the dependent variable. Thus, the strength of each predictor (independent variable) influencing the criterion (dependent variable) can be investigated via an unstandardized Beta coefficient. The regression coefficient explains the average amount of change in the dependent variable that is caused by a unit change in the independent variable. The independent variable that has the larger value of the Beta coefficient brings more support to the independent variable as it is a more important determinant in predicting the dependent variable. In this case our equation of the model is stated as follows:

\subsection{Result and Discussion}

The Effect of Government Policy on Hotel Investment

According to Sudhan (2012) listed out that level of corruption, political stability, risk of military invasion, intellectual property protection, pricing strategy, wage regulation like overtime payment and minimum wage and salary, workweek regulation, mandatory employee benefit, safety regulation, and product levels as factors that the hotel investment.

According to Juan et al (2011) Governmental policy is one of the major factors that affect the hotel investment which can be frequently existed by the public administrations. Austin (2013) also stated that continuous changes in government policy and political issue and their massive meddling in controlling the hotel investment have a great effect because of its role in creating political instability and legal system.

To support the data obtained in a quantitative way about the government policy, interviewees were prepared and conducted with hotel managers, south Gondar zone culture and tourism office head, south Gondar zone land administration office, municipality office, and investment office. Hence, the following point is generalized, Government policy is one of the major factors for hotel investment in the study area, because of complex bureaucracy like land lease, tax easement, license process problem, absence of single body decision-maker (the licensing process is entails to contact different government offices such as land administration, investment office, municipality, trade office, culture, and tourism office). This circular process has its own ups and downs and leads to monotonous situation for hotel investors. The policy is not convenient for service industry; it gives priority the manufacturing and agriculture sectors. Moreover, the government has no clear policy to solve the serious problem if political instability and crises might be happening in the hotel, and there is no sustainable hotel property protection policy.

In addition, the researcher was analyses the document based on content analysis. Hence, according to regulation of Federal Negarit Gazeta of the Federal Democratic Republic of Ethiopia (2012) article ' 3 ' number '10' says that "investment area like hotels (excluding star-designated hotels), motels, and tea rooms. Coffee shops, bars, nightclubs, and restaurants which do not have international standards are not eligible for exemption from the payment of customs duty. In addition to this towards issuance of investment permit the article 16 says,

"No investors may, at any time, be allowed to invest by holding both foreign and domestic investment permit." Furthermore, Federal Negarit Gazette No4 November 29th, 2012 it says that "unlike other manufacturing and agriculture investment areas the investment area of hotel and tourism is not eligible for income tax exemption."' This type's policy might lead to devastating hotel investment.

Effects of Socio-Cultural Factor on Hotel Investment

In terms of the relative importance of the independent variables to hotel investment, socio-cultural factors were found to be the other contributor to hotel investment with its effect magnitudes of $0.337(33.7 \%)$. This result is directly in line with the previous research which was conducted by Xiaoping et al (2019) which states that sociocultural factors are one of the factors that affect hotel investment and an emphasis on the changes in the features 
of the local community day to day life of activities at the destination and which is basically related with the transformation in local community traditional values, norms, identities, and awareness. Hence, these impacts are very complicated to reckon and estimate and develop slowly over a period in a modest approach.

Cooper et al (2013) also supports that socio-cultural factors affect hotel investment. The authors suggest that the modification of local community awareness can be apparent in a short period of time but there are also other critical things like society values, beliefs, and cultural practice, lifestyle, custom those required systematic long term, and expected gradual changes.

Socio-cultural factor is the major factor affecting the hotel investment. Accordingly; "the local community of South Gondar Zone has low level of attitude to consuming hotel products and services; have low entertainment habit and awareness problems on the hotel industry are the core problems of socio- cultural for hotel investment."

The Effect of the Economic Factor on Hotel Investment

Economic factors influenced hotel investment in terms of economical values. In this research, economic factors were found to have a significant impact (with a coefficient of 0.24 ) on hotel investment. This result is in line with the previous research which was conducted by Sudhan (2012) that listed out the basic components of economic factors that affect hotel investment. Accordingly, the author stated that the economic system of the country, government intervention in the free market, exchange rate and suitability of host country currency, the efficiency of the financial market(the local investment market), the quality of tourism infrastructure, total economic advantages of the host country, skilled level of workforce and their costs, the level of education level in the country economy, the local economic business cycle stage, economic growth rate, average incomes of the local community, unemployment rate, inflation and interest rate are the major factors that affect the hotel investors in various ways.

According to the data obtained from hotel and tourism experts, investment office head and hotel managers mentioned that;

Economic factors such as land lease cost, insufficiency of reserved land for hotel investment, low local living standard of community to consume the hotel product and service are some of the factors that affect the hotel investment in the south Gondar administration zone. Another important factor which affects hotel investment in the zone is poor facilitation in hotel building process in the zone, high amount of compensation for local landholders/owners.

The Effect of Infrastructure on Hotel Investment

Infrastructure is another important element in this finding which highly influences the hotel investment with its unstandardized coefficient of $15.5 \%$. Tesfay (2018) has also found this factor to be the influencing factor of the hotel investment. The author stated that infrastructure facilities like faded roads unbalanced education and health service have a great influence on investment activities. Similarly, Juan et al (2011) argues that infrastructures are the factor that affects hotel investment. The above-stated researchers tried to identify infrastructure like an airport, convention center, new communication infrastructure like digital terrestrial television (DTT), the wider geographical coverage of broadband internet can affect the hotel investment in various degrees. Infrastructure is the basis of hotel development and utilization of existing destination resources. Infrastructure includes a large number of services, necessary to meet the needs of the tourists and increase satisfaction during their at the investment destination (Sonja et al, 2016).

From interviews with south Gondar administration zone investment offices and expert say "Currently, infrastructures problems like shortage of electric power, the absence of an airport transport system, and the shortage of enough water supplies affect the hotel investment in the south Gondar Administrative Zone."

The Effect of Geographical Location on Hotel Investment

The current research has found out similar result with research which was conducted by Yang et al (2014) which states that the location of the investment site is one of the basic factors for hotel investment. According to the key interviewee informant's geographical location is another factor affecting the hotel investment. Accordingly:

Even though the zone is full of tourism heritages and good climate conditions, the hotel investment yet is so poor due to the problem of geographical location. The zone is far away from the airport and not yet have world heritage which attracts more international tourists. As the result, the tourist does not stay here more time and the tourists prefer to visit Lalibela, Bahirdar, and Gondar. They also said that the geographical nature of the zone is rocky (14\%) and mountainous (46\%) these leads to fear for hotel investors to invest in these types of nature due to limited capability of capital expenditure.

\section{Conclusion}

$>$ This study was initiated to examine factors affecting hotel investment in the South Gondar Administration Zone. More specifically, in this study, five predictors namely government policy, sociocultural, economy, infrastructure, and location factors are assumed to be more important in influencing 
hotel investment.

$>$ According to the Pearson Correlation Analysis, it can be clearly seen that the two variables namely government policy, socio-cultural have a positive and strong correlation with the dependent variable i.e. hotel investment. The rest of the variables like the economy, infrastructure, location, and have a positive and moderate correlation with customer retention. It can be concluded that there is a moderate to a strong association between the dependent variables and hotel investment.

$>$ The examination results of regression analysis indicated that government policy, socio-cultural, economy, infrastructure, and location; positively affects hotel investment depending on their order of importance from most determinants to the least.

$>$ Governmental policy is the most important criterion in hotel investment in the study area. This finding indicates that most investors are sensitive with respect to policy.

$>$ The second most important element in the finding is socio-cultural which highly influences the hotel investment.

$>$ The regression analysis result also indicated that the economy is the third important element in the finding.

$>$ Moreover, infrastructure is the least important variable in influencing hotel investment.

$>$ Finally, location is an important element which influences the hotel investment.

\section{Recommendation}

$>$ According to the findings, government policy was found statistically significant and affects hotel investment. Hence, it would be helpful if the government bodies (culture and tourism office, investment office, land administration, and revenue office) focus on making standard and feasible policy which can be suitable for the hotel investor through reducing the complexity of policy and could ensure the commitments of the local responsible bodies to enhance the hotel investment.

$>$ In addition to this, the socio-cultural factor was found statistically significant and affects hotel investment. Hence, it would be good to give training and awareness local community about the hotel industry, and the local government would make hotel and tourism festival celebrities in order to create a good image of the hotel.

$>$ The study revealed that the economic factor was found statistically significant and affects hotel investment. Consequently, the local government would work with the hotel investor and communities to solve the economic problems like investment land price, inflation of local commodities amount taxation volume.

$>$ Based on the findings of the study, infrastructure was found statistically significant and affects hotel investment. As a result, tourism infrastructure like a standard transport system to and from the destination, consistent power, and water supply would be accessed.

\section{Reference}

Brook, C. (2008). Introductory econometrics of finance ( $2^{\text {nd }}$ ed.). The ICMA Center.

Callan, R.J. \& M.K. \& Hoyes, (2000). Preliminary assessment of the function and conference service product at a UK stately home: Tourism Management. 21: 571-581.

Cooper, C., Fletcher, J.E., Gilbert, D. \& Wanhill, S. (2013). Tourism: Principles and Practice; Pitman Publishing: New York, NY, USA.

Douglas, C., Montgomery, Elizabeth A., Peck \& Geogoffrey, V. (2012). Introduction to linear regression: $5^{\text {th }}$ edition: publisher;Wiley.

Ebisa, C., Andualem, \& Gudeta (2013). Hotel sector investment in Ethiopia: Journal of business management, $1(2)$

Federal Negarit Gazeta of the federal democratic republic of Ethiopia (2012) article '3' and 16 number '10'

Federal Negarit Gazette (2012). Hotel and tourism eligible for income: No4 November 29th, tax exemption.

Field, A. (2009). Discovering Statistics Using SPSS ( $3^{\text {rd }}$ ed). Sage Publications: London

Girmachew, \& Gashaw (2018). Challenges and opportunities of investment in Ethiopia: journal of management, 4

Goldin (2010). The economic case for tourism, UNWTO/South Africa International Summit on tourism, Sport and Mega-events 25 February: Reducing poverty through tourism: Geneva

International labor organization (2010). Developments and Challenges in the Hospitality and Tourism Sector: Issues Paper for Discussion at the Global Dialogue Forum for the Hotels, Catering, Tourism Sector, Geneva, Switzerland.

International labor organization (2017). Employment Intensive Investment Program: Creating jobs through public investment: Trends (Geneva).

International labor organization (2017). Employment Intensive Investment Program: Creating jobs through 
public investment: Trends (Geneva).

Ivica, B. (2016). Hotel management and quality of hotel services: journal of process management - new technologies, international vol. 4, (1), 2016. : Vocational school, vukovar, Croatia

Januszewska, M. \& Januszewski, M. (2009). Uwarunkowania procesów inwestycyjnych dla podmiotów gospodarki turystycznej w powiecie jeleniogórskim. Ekonomiczne Problemy Turystyki, 11(1), 76-80

Kebede, E. (2014). The Hotel Industry in Ethiopia: The Best is yet to come: Addis Standard. Retrieved from https://allafrica.com/stories/201412031381.html

Kothari, C.R. (2004). Research Methodology: Methods and Techniques. (3 $3^{\text {rd }}$ ed). New Delhi: New Age International Limited.

Krisada, S. (2019). The factors affecting decisions on investment patterns for financial problem solving in the accommodation business: African Journal of Hospitality, Tourism and Leisure, 8 (1)

Mankiw, G. (2009). Macroeconomics, Worth Publishers, New York, USA.

Mariana, Z. Marinela, D. \& Luiza, I. (2016). Return on Investment Indicator for Measuring the Profitability of Invested Capital: Valahian Journal of Economic Studies, 0 (0)

Mathis, L. \& Jackson, H. (2008). Human Resource Management ( $8^{\text {th }}$ ed.). West Publishing Company.

Matwang, A. \& Fredrick, L. (2000). Determinants and Constraints to private Investment: The Case of Kenya

Milota, V., Lvana S. \& Kristina, P. (2019). Age and educational diversification of hotel employees and its impact on turn-over: faculty of economics, Matej Bel University, Tajovského

Monappa, A. \& Saiyadain, M. (2008). Personnel Management (2 nd ed.). Tata McGraw-Hill, New Delhi.

Niskanen, J. \& Niskanen, M. (2007;2013). Yritysrahoitus, Edita Publishing Oy.

Nosta \& Jhon (2012). Pest analysis: an essential marketing tool for today’s digital world

Oxford dictionaries (2014).Definition of hotel

Pallant (2005). SPSS Advisal manual: Stape gaid to beta Analysis using SPSS softer window Version 12 Chicago, Illinoie: Universal open press.

Rushmore, S.(2001). Hotel investment handbook: in a case of United States of America. HVS Global Hospitality service pp671

Sudhana, P. (2012). Studi kelayakan Usaha hotel: manga besar, jakarta. Excel teknik konsultama

Sudhana, P. (2012). Studi kelayakan Usaha hotel: manga besar, jakarta. Excel teknik konsultama

Tesfay, E. G. (2018). Assessment of the determinants of investment activities in Nekemte town: International journal of research Granthaalayah, 16 (11)

Tzeng, G.H., M.H. Teng, J.J. Chen \& Opricovic, S. (2002) multi criteria selection for a restaurant location in Taipei: Int. J. Hosp. Manage., 21: 171-187.

United Nations Framework Convention on Climate Change (2015). Conference of the Parties, Twenty-first session, Paris: 30 November to 11 December 2015. Agenda item 4(b) Adoption of the Paris Agreement (Paris).

Voicu, A. (2008). Passive vs. active investment management strategies // the financial planning association, spring.

Wilkinson \& Jim (2013). Investment analysis: http:// strategiccfo.com/investment-analysis/accessed on june29 2020

Willian, G. Cochran (1997). Sampling techniques: $3^{\text {rd }}$ edition Harvard University

Wojciech, Dziemianowicz, Julita, Lukomska, Adam, A. \& Ambroziak (2018). location factor in foreign direct investment at the local level: a case of Polland.avaiable at https://rsa.tandfonline.com/eprint.

Xiaoping, Z., Yong, Y. \& June, L. (2019). Sociocultural impacts of tourism on residence of world cultural heritage sites in china

Yang (2012). Studied how hotels do choice their location In Beijing: International Journal of Hospitality Management

Zamani-Farahani \& Musa, G. (2012). The relationship between Islamic religiosity and residents' perceptions of socio-cultural impacts of tourism in Iran: Case studies of Sare'in and Masooleh. Tour Manag, 33 